\title{
Respon Pertumbuhan dan Produksi Kacang Tanah (Arachis hypogaea L.) terhadap Sistem Tanam Alur dan Pemberian Jenis Pupuk
}

\author{
Growth Respond and Production of Peanut (Arachis hypogaea L.) to Deep Furrow Planting System \\ and Application of Different Fertilizers
}

\author{
Rizal Mahdi Kurniawan, Heni Purnamawati* dan Yudiwanti Wahyu E.K
}

\author{
Departemen Agronomi dan Hortikultura, Fakultas Pertanian, Institut Pertanian Bogor (Bogor Agricultural \\ University), Jl. Meranti, Kampus IPB Darmaga, Bogor 16680, Indonesia \\ Telp.\&Faks.62-251-8629353 e-mail agronipb@indo.net.id \\ *Penulis untuk korespondensi: heni_purnama@yahoo.com
}

Disetujui 6 November 2017/Published online 14 November 2017

\begin{abstract}
This research was to determine the effect of deep furrow planting system and provision of fertilizers groove on the growth and production of peanut (Arachis hypogaea L.). This research was conducted in KP Leuwikopo Dramaga IPB, Bogor in February - June 2013. This research was used a split plot design by treatment consists of two factors, they were planting system as main plots and fertilize type as the subplot. The results showed that the treatment system of deep furrow was signifficant on the productivity of dry seeds, dry peas productivity, and dry weight of seeds per plant better than conventional planting systems. This shown that system of deep furrow treatment yielding productivity 2.93 tons/ha dry pods, while system plant conventional equal to 2.55 tons/ha dry pods. Peanut planting systems on deep furrow planting system can improved efficiency in the used of plant to utilize nutrients from organic and inorganic fertilizers, so that the growth and yield of groundnut for the better. Aplication of organic manure of chicken + Dolomite + NPK Phonska respond to growth and the average plant yield better than other types of fertilizers.
\end{abstract}

Keywords: peanut, productivity, deep furrow planting system

\begin{abstract}
ABSTRAK
Penelitian ini bertujuan untuk mempelajari pengaruh sistem tanam alur dan pemberian jenis pupuk terhadap pertumbuhan dan produksi kacang tanah (Arachis hypogaea L.). Penelitian dilaksanakan di KP Leuwikopo IPB Dramaga, Bogor pada bulan Februari - Juni 2013. Percobaan menggunakan rancangan petak terbagi (Split Plot Design) dengan perlakuan terdiri dari dua faktor, yaitu sistem tanam alur sebagai petak utama dan jenis pupuk sebagai anak petak. Hasil penelitian menunjukkan bahwa perlakuan sistem tanam alur meningkatkan daya hasil pada produktivitas biji kering, produktivitas polong kering, dan bobot kering biji per tanaman lebih baik dibandingkan sistem tanam konvensional. Hal tersebut ditunjukkan dengan perlakuan sistem tanam alur yang memiliki produktivitas 2.93 ton/ha polong kering, sedangkan sistem tanam konvensional sebesar 2.55 ton/ha polong kering. Sistem budidaya kacang tanah pada sistem tanam alur dapat meningkatkan efisiensi tanaman dalam memanfaatkan unsur hara yang telah diberikan baik pupuk organik maupun anorganik, sehingga pertumbuhan dan hasil tanaman kacang tanah menjadi lebih baik. Pemberian jenis pupuk kandang ayam + Dolomit + NPK memberikan respon terhadap pertumbuhan dan daya hasil rata-rata tanaman yang lebih baik dibandingkan jenis pupuk lainnya.
\end{abstract}

Kata kunci: kacang tanah, produktivitas, sistem tanam alur 


\section{PENDAHULUAN}

Kacang tanah (Arachis hypogaea L.) di Indonesia merupakan komoditas pertanian terpenting setelah kedelai yang memiliki peran strategis pangan nasional sebagai sumber protein dan minyak nabati. Marzuki (2009) menyatakan bahwa kacang tanah mengandung lemak 40-50\%, protein $27 \%$, karbohidrat $18 \%$, dan vitamin. Kacang tanah dimanfaatkan sebagai bahan pangan konsumsi langsung atau campuran makanan seperti roti, bumbu dapur, bahan baku industri, dan pakan ternak, sehingga kebutuhan kacang tanah terus meningkat setiap tahunnya sejalan dengan peningkatan jumlah penduduk (Balitkabi 2008).

Produktivitas rata-rata kacang tanah nasional dari tahun 2008 hingga 2012 mengalami sedikit peningkatan. Data BPS (Badan Pusat Statistik) menyebutkan bahwa produktivitas kacang tanah pada tahun 2008 sekitar 1.21 ton/ha, pada tahun 2012 terjadi peningkatan menjadi 1.26 ton/ha. Produktivitas kacang tanah di Indonesia tergolong rendah, jika dibandingkan dengan negara USA, Cina, dan Argentina yang sudah mencapai lebih dari 2 ton/ha. Peningkatan produktivitas kacang tanah di Indonesia tidak diikuti dengan peningkatan produksi kacang tanah, produksi kacang tanah nasional masih tergolong rendah, bahkan dari tahun 2008 hingga 2012 terus mengalami penurunan. Tahun 2008 produksi kacang tanah sekitar 770054 ton, dan tahun 2012 sekitar 709063 ton. Kemampuan produksi rata-rata hanya sekitar 1 ton/ha biji kering. Salah satu penyebab produktivitas kacang tanah yang masih rendah karena proses pengisian polong kacang tanah belum maksimal, masih banyak ditemukan polong yang hanya terisi setengah penuh bahkan cipo (Kasno 2005). Hasil polong kacang tanah di tentukan oleh fotosintat yang di akumulasi ke dalam kulit dan biji kacang tanah (Kadekoh 2007). Bahan kering untuk pengisian biji pada kacang tanah diduga lebih banyak diperoleh dari fotosintesis selama pengisian biji (Purnamawati et al. 2010).

Permasalahan yang dihadapi dalam meningkatkan produksi kacang tanah nasional disebabkan oleh beberapa hal diantaranya: a) Penerapan teknologi belum dilakukan dengan baik, sehingga produktivitas belum optimal misalnya, pengolahan lahan kurang optimal sehingga drainase buruk dan struktur tanah padat, pemeliharaan tanaman kurang optimal sehingga serangan OPT tinggi b) Penggunaan benih bermutu masih rendah, c) Penggunaan pupuk hayati dan organik masih rendah (Dirjen Tanaman Pangan 2012). Rendahnya hasil kacang tanah juga dipengaruhi jumlah bulan basah kurang dari tiga bulan sehingga tanaman mengalami kekeringan. Penurunan hasil kacang tanah akibat kekeringan berkisar atara $22-96 \%$ tergantung pada fase pertumbuhan saat kekeringan terjadi (Harsono 2007).

Produksi kacang tanah dapat ditingkatkan dengan memperhatikan beberapa sasaran yaitu luas tanam, luas panen, produksi, dan produktivitas (Pitojo 2005). Peningkatan produksi kacang tanah dapat dicapai melalui beberapa strategi, diantaranya: a) Peningkatan produktivitas, upaya yang dilakukan adalah menerapkan teknologi produksi yang tepat guna, pengembangan dan penerapan teknologi budidaya terbaru, dan perlindungan tanaman dari OPT. b) Perluasan areal lahan budidaya dan optimalisasi lahan dilakukan dengan membuka lahan baru (sawah), mengoptimalkan lahan dengan memanfaatkan lahan marjinal dan lahan pertanian lainnya (Dirjen Tanaman Pangan 2012).

Sumarno et al. (2001) menyatakan bahwa kacang tanah membutuhkan unsur hara N, P, K, dan Ca dalam jumlah yang cukup, sehingga membutuhkan pemberian kapur dan pemupukan baik organik maupun anorganik. Kari et al. (2000) menambahkan bahwa penambahan bahan organik dapat meningkatkan efisiensi penyerapan unsur fosfor (P), yang dapat meningkatkan agregasi tanah sehingga tanah menjadi lebih gembur, dan sangat menguntungkan untuk pertumbuhan ginofor. Pengapuran juga dapat mengatasi lahan asam untuk meningkatkan produksi. enelitian ini bertujuan untuk mempelajari pengaruh sistem tanam alur dan pemberian jenis pupuk terhadap pertumbuhan dan produksi kacang tanah (Arachis hypogaea L.).

\section{BAHAN DAN METODE}

Penelitian dilaksanakan di Kebun Percobaan IPB Leuwikopo, Dramaga, Bogor. Periode waktu pelaksanakan penelitian dari bulan Februari sampai Juni 2013. Bahan yang digunakan meliputi kacang tanah varietas Gajah, pupuk kandang ayam dengan dosis 1 ton ha ${ }^{-1}$, dan pupuk majemuk NPK Phonska dengan dosis 200 $\mathrm{kg} \mathrm{ha}{ }^{-1}$. Pengendalian OPT menggunakan profenofos, mankozeb dan karbofuran. Kapur pertanian yang digunakan adalah Dolomit dengan dosis $600 \mathrm{~kg} \mathrm{ha}^{-1}$. Alat yang digunakan terdiri dari alat budidaya pertanian, sprayer, timbangan digital, LICOR LI-3000L, dan oven pengering.

Percobaan menggunakan rancangan petak terbagi (Split Plot Design) dengan perlakuan terdiri dari dua faktor, yaitu sistem tanam alur 
sebagai petak utama dan jenis pupuk sebagai anak petak. Petak utama merupakan faktor perlakuan sistem tanam alur terdiri dari dua taraf yaitu sistem tanam alur dan sistem tanam konvensional. Pemberian jenis pupuk sebagai anak petak yang terdiri dari tiga taraf yaitu pupuk kandang ayam, pupuk kandang ayam + kampur Dolomit, dan pupuk kandang ayam + kapur Dolomit + pupuk NPK Phonska. Terdapat 6 kombinasi perlakuan yang diulang sebanyak 3 kali.

Perlakuan konvensional pemberian kapur Dolomit $\mathrm{CaMg}(\mathrm{CO} 3) 2$ dan pupuk kandang dilakukan bersamaan saat pengolahan tanah yaitu dua minggu sebelum tanam dengan cara disebar diatas tanah yang akan diolah, sedangkan pupuk NPK diberikan bersamaan saat tanam. Pada perlakuan sistem tanam alur Dolomit, pupuk kandang, dan pupuk NPK diberikan sehari sebelum tanam dengan dosis yang sama pada perlakuan konvensional. Pupuk tersebut diberikan dalam alur dengan kedalaman dan lebar alur 20 $\mathrm{cm}$ sehingga dalam satu alur tanaman terdapat campuran antara pupuk kandang, kapur Dolomit, dan pupuk NPK tergantung perlakuan. Setelah campuran tersebut dimasukan ke dalam alur, kemudian alur di tutup dengan tanah dan benih ditanam.

Pemeliharaan meliputi penyulaman, penyiraman, penyiangan gulma, dan pengendalian hama penyakit. Penyiangan gulma dilakukan pada saat 3 MST, 5 MST, dan 12 MST. Pengendalian hama penyakit dilakukan dengan penyemprotan prefenofos dan mankozeb dengan konsentrasi 4 $\mathrm{ml} \mathrm{l}^{-1}$. Pengendalian hama penyakit tanaman dilakukan pada saat 6 MST dan 11 MST. Pembubunan dilakukan dua kali pada perlakuan konvensional saat 3 MST dan 5 MST. Pemanenan dilakukan ketika umur tanaman 15 MST.
Pengamatan pada tanaman kacang tanah dilakukan dua tahap yaitu pengamatan saat pertumbuhan tanaman dan pengamatan saat panen, pengamatan dilakukan untuk semua perlakuan. Pengamatan destruktif dilakukan pada saat tanaman berumur 4, 6, 10, dan 15 MST. Pengamatan meliputi: (1) tinggi tanaman, (2) jumlah cabang pada tanaman, (3) indeks luas daun (ILD), dan (4) bobot kering brangkasan. Pengamatan komponen produksi dan produktivitas tanaman kacang tanah yang dilakukan pada saat panen untuk setiap perlakuan dari setiap ulangan secara ubinan, luasan ubinan yaitu $1 \mathrm{~m}$ x $1 \mathrm{~m}$. Peubah yang diamati adalah: (1) jumlah dan persentase polong total, penuh, setengah penuh dan cipo, (2) bobot kering polong, (3) bobot kering 100 butir, (4) indeks panen, dan (5) produktivitas polong kering dan biji kering kacang tanah.

\section{HASIL DAN PEMBAHASAN}

\section{Tinggi tanaman}

Hasil sidik ragam menunjukkan bahwa perlakuan sistem tanam tidak memberikan pengaruh nyata terhadap peubah tinggi tanaman. Perlakuan jenis pupuk memberikan pengaruh nyata pada tinggi tanaman saat tanaman berumur 6 MST dan 10 MST. Tinggi tanaman keterkaitan dengan kemampuan tanaman untuk mendapatkan sinar matahari yang lebih banyak untuk proses fotosintesis. Sutrisno (2004) menyatakan bahwa bertambahnya tinggi tanaman dipengaruhi oleh ketersediaan unsur hara didalam tanah yang seimbang, antara lain $\mathrm{N}, \mathrm{P}$, dan $\mathrm{K}$, unsur tersebut mendorong pembelahan sel, terutama sel-sel meristem sehingga tanaman tumbuh tinggi.

Tabel 1. Rata-rata tinggi tanaman kacang tanah pada perlakuan tunggal sistem tanam dan jenis pupuk

\begin{tabular}{lcccc}
\hline \multirow{2}{*}{ Perlakuan } & \multicolumn{4}{c}{ Tinggi tanaman minggu ke (cm) } \\
\cline { 2 - 5 } Sistem Tanam & 4 & 6 & 10 & 15 \\
Alur & 11.39 & $23.95 \mathrm{a}$ & $64.52 \mathrm{a}$ & 89.61 \\
Konvensional & 10.31 & $23.24 \mathrm{a}$ & $63.41 \mathrm{a}$ & 83.01 \\
Jenis pupuk & & & \\
Pukan & 10.03 & $21.04 \mathrm{~b}$ & $60.7 \mathrm{~b}$ & 80.94 \\
Pukan+Dolomit & 10.51 & $24.2 \mathrm{ab}$ & $62.13 \mathrm{~b}$ & 91.72 \\
Pukan+Dolomit+NPK & 12.02 & $25.53 \mathrm{a}$ & $69.69 \mathrm{a}$ & 86.25 \\
\hline
\end{tabular}

Keterangan : angka-angka pada kolom faktor tunggal yang sama menunjukkan tidak berbeda nyata pada uji Duncan taraf 5\%

Hasil sidik ragam menunjukkan bahwa interaksi antara perlakuan sistem tanam dan jenis pupuk memberikan pengaruh nyata pada tinggi tanaman 10 MST. Sistem tanam alur dengan pemberian jenis pupuk kandang + Dolomit dan pupuk kandang + Dolomit + NPK memberikan tinggi tanaman lebih baik dibandingkan hanya pemberian jenis pupuk kandang, sedangkan sistem tanam konvensional dengan pemberian pupuk kandang + Dolomit + NPK memberikan tinggi tanaman lebih baik dari kombinasi perlakuan lainnya (Tabel 2). Jumakir et al. (2000) 
menyatakan bahwa kombinasi antara kapur dan pemupukan menghasilkan pertumbuhan kacang tanah lebih tinggi dibanding tanpa kapur dan pupuk.

Tabel 2. Rata-rata tinggi tanaman kacang tanah 10 MST pada interaksi perlakuan sistem tanam dan jenis pupuk

\begin{tabular}{lccc}
\hline \multirow{2}{*}{ Sistem tanam } & \multicolumn{3}{c}{ Jenis pupuk } \\
\cline { 2 - 4 } & Pupuk kandang & Pupuk kandang + Dolomit & Pupuk kandang + Dolomit + NPK \\
\hline Alur & $60.38 \mathrm{~b}$ & $65.34 \mathrm{ab}$ & $67.83 \mathrm{ab}$ \\
Konvensional & $59.75 \mathrm{~b}$ & $58.93 \mathrm{~b}$ & $71.56 \mathrm{a}$ \\
\hline \multicolumn{2}{l}{ Keterangan : } & angka-angka pada kolom faktor tunggal yang sama pada tiap peubah diikuti huruf yang sama menunjukkan tidak
\end{tabular}

\section{Jumlah cabang}

Hasil sidik ragam menunjukkan bahwa perlakuan sistem tanam dan jenis pupuk tidak berpengaruh nyata terhadap jumlah cabang tanaman pada 4 MST hingga 10 MST, sedangkan pada 15 MST sistem tanam alur berpengaruh nyata terhadap sistem tanam konvensional. Sistem tanam alur memiliki jumlah cabang rata- rata 7.72 cabang, sedangkan sistem tanam konvensional 6.61 cabang (Tabel 3).

Tabel 3. Rata-rata jumlah cabang tanaman kacang tanah pada perlakuan tunggal sistem tanam dan jenis pupuk

\begin{tabular}{lcccc}
\hline \multirow{2}{*}{ Perlakuan } & \multicolumn{4}{c}{ Jumlah cabang tanaman pada minggu ke } \\
\cline { 2 - 5 } Sistem Tanam & 4 & 6 & 10 & 15 \\
Alur & 5.94 & 7.31 & 7.47 & $7.72 \mathrm{a}$ \\
Konvensional & 5.58 & 6.75 & 6.77 & $6.61 \mathrm{~b}$ \\
Jenis pupuk & & & & \\
Pukan & 5.83 & 6.62 & 6.61 & $7.16 \mathrm{a}$ \\
Pukan+Dolomit & 5.67 & 7.17 & 6.77 & $6.79 \mathrm{a}$ \\
Pukan+Dolomit+NPK & 5.79 & 7.29 & 8 & $7.54 \mathrm{a}$ \\
\hline
\end{tabular}

Keterangan : angka- angka pada kolom faktor tunggal yang sama pada tiap peubah diikuti huruf yang sama menunjukkan tidak berbeda nyata pada uji Duncan taraf 5\%

Interaksi perlakuan sistem tanam dengan jenis pupuk berpengaruh sangat nyata terhadap bobot kering brangkasan tanaman pada 6 MST dan berpengaruh nyata pada 10 MST. Kombinasi sistem tanam alur dengan pupuk kandang + Dolomit + NPK menunjukkan bobot kering brangkasan tanaman pada 6 MST lebih besar dari perlakuan lainnya, sedangkan bobot kering brangkasan tanaman saat 10 MST pada perlakuan sistem tanam alur maupun konvensional dengan pemberian jenis pupuk kandang + Dolomit + NPK memberikan bobot kering lebih besar dari kombinasi perlakuan jenis pupuk lainnya.

\section{Jumlah dan persentase polong per tanaman}

Jumlah polong per tanaman diklasifikasikan menjadi tiga jenis polong yaitu, polong isi penuh, isi setengah penuh, dan cipo. Perlakuan sistem tanam dan jenis pupuk tidak memberikan pengaruh nyata terhadap jumlah dan persentase polong penuh, setengah penuh, cipo, dan polong total. Jumlah polong penuh pada sistem tanam alur sebanyak 18.86 polong dan sistem tanam konvensional sebanyak 17.97 polong. Persentase polong penuh pada jenis pupuk kandang + Dolomit + NPK memberikan hasil persentase polong penuh $88.21 \%$ dari total polong. Hal ini diduga terbentuknya polong penuh atau cipo dipengaruhi oleh kemampuan tanaman mengakumulasi fotosintat untuk pengisian polong. Yudiwanti et al. (2008) menyatakan bahwa persentase polong terisi penuh dan cipo merupakan cerminan partisi fotosintat.

Bobot kering polong, bobot kering 100 butir dan indeks panen tanaman

Bobot kering polong per tanaman didapatkan dari refraksi kadar air polong per tanaman antara bobot basah dan bobot kering polong per tanaman untuk mengetahui bahan kering yang terdapat pada polong kacang tanah. Hasil sidik ragam menunjukkan bahwa perlakuan sistem tanam berpengaruh sangat nyata dan perlakuan jenis pupuk berpengaruh nyata terhadap bobot kering polong per tanaman. Bobot kering 100 butir pada perlakuan sistem tanam dan jenis pupuk tidak berpengaruh nyata (Tabel 4). Hal ini diduga berat 100 butir pada kacang tanah dipengaruhi oleh varietas atau genetik. Ratnapuri 
(2008) menyatakan bahwa rata- rata bobot kering 100 butir kacang tanah varietas Gajah berbeda nyata terhadap kacang tanah varietas Jepara, Panter, Garuda Boga, dan Biawak.

Indeks panen merupakan perbandingan antara hasil distribusi asimilasi biomassa ekonomis dengan biomassa keseluruhan atau menggambarkan bobot kering total tanaman. Hasil penelitian menunjukkan indeks panen berpengaruh nyata terhadap perlakuan jenis pupuk. Indeks panen pada pemberian jenis pupuk kandang + Dolomit + NPK lebih besar dibandingkan hanya pemberian jenis pupuk kandang. Hal ini diduga pada jenis pupuk kandang + Dolomit + NPK membagi bobot keringnya untuk tanaman hasil panen ekonomis, sedangkan jenis pupuk kandang membagi bobot keringnya untuk tanaman hasil panen ekonomis sedangkan jenis pupuk kandang membagi bobot keringnya untuk panen biologis.

Tabel 4. Bobot kering polong per tanaman, bobot kering 100 butir dan indeks panen kacang tanah pada perlakuan tunggal sistem tanam dan jenis pupuk

\begin{tabular}{lccc}
\hline Perlakuan & Bobot kering polong per tanaman & Bobot kering 100 butir & Indeks panen \\
\hline Sistem Tanam & & & \\
Alur & $29.30 \mathrm{a}$ & 51.25 & $49.8 \mathrm{a}$ \\
Konvensional & $25.55 \mathrm{~b}$ & 50.34 & $49.21 \mathrm{a}$ \\
Jenis pupuk & & 47.54 & \\
Pukan & $25.23 \mathrm{~b}$ & 52.29 & $46.98 \mathrm{a}$ \\
Pukan+Dolomit & $26.77 \mathrm{~b}$ & 52.56 & $49.31 \mathrm{ab}$ \\
Pukan+Dolomit+NPK & $30.27 \mathrm{a}$ & $52.22 \mathrm{a}$ \\
\hline
\end{tabular}

Keterangan : angka- angka pada kolom faktor tunggal yang sama pada tiap peubah diikuti huruf yang sama menunjukkan tidak berbeda nyata pada uji Duncan taraf 5\%

Hasil sidik ragam menunjukkan adanya interaksi nyata antara sistem tanam dan jenis pupuk terhadap bobot kering polong per tanaman. Sistem tanam alur terhadap pemberian jenis pupuk kandang dan pupuk kandang + Dolomit menghasilkan bobot kering polong per tanaman lebih baik dibandingkan sistem tanam konvensional, sedangkan pemberian jenis pupuk kandang + Dolomit + NPK terhadap perlakuan sistem tanam alur maupun konvensional memberikan bobot kering polong per tanaman sama baiknya (Tabel 5).

Tabel 5. Bobot kering polong pertanaman hasil interaksi perlakuan sistem tanam dan jenis pupuk

\begin{tabular}{|c|c|c|c|}
\hline \multirow{2}{*}{ Sistem tanam } & \multicolumn{3}{|c|}{ Jenis pupuk } \\
\hline & Pupuk kandang & Pupuk kandang + Dolomit & Pupuk kandang + Dolomit + NPK \\
\hline Alur & 28.01ab & $28.57 \mathrm{ab}$ & $31.32 \mathrm{a}$ \\
\hline Konvensional & $22.44 c$ & $24.97 \mathrm{bc}$ & 29.27a \\
\hline
\end{tabular}

Hasil interaksi antara sistem tanam dan jenis pupuk terhadap indeks panen tanaman menunjukkan bahwa kombinasi antara sistem tanam konvensional dengan pemberian jenis pupuk kandang memberikan indeks panen tanaman paling rendah dibandingkan kombinasi perlakuan lainnya (Tabel 6).

Tabel 6. Indeks panen tanaman kacang tanah hasil interaksi perlakuan sistem tanam dan jenis pupuk

\begin{tabular}{lccc}
\hline \multirow{2}{*}{ Sistem tanam } & \multicolumn{3}{c}{ Jenis pupuk $^{\text {a }}$} \\
\cline { 2 - 4 } & Pupuk kandang & Pupuk kandang + Dolomit & Pupuk kandang + Dolomit + NPK \\
\hline Alur & $50.4 \mathrm{a}$ & $48.39 \mathrm{ab}$ & $50.61 \mathrm{a}$ \\
Konvensional & $43.56 \mathrm{~b}$ & $50.22 \mathrm{a}$ & $53.84 \mathrm{a}$ \\
\hline \multicolumn{2}{l}{ Keterangan : } & $\begin{array}{l}\text { angka- angka pada kolom faktor tunggal yang sama pada tiap peubah diikuti huruf yang sama menunjukkan tidak } \\
\text { berbeda nyata pada uji Duncan taraf 5\% }\end{array}$
\end{tabular}

\section{Produktivitas tanaman}

Hasil sidik ragam menunjukkan bahwa produktivitas biji kering maupun polong kering pada perlakuan sistem tanam alur lebih baik dibandingkan perlakuan sistem tanam konvensional. Produktivitas rata-rata pada sistem tanam alur adalah 1.90 ton/ha biji kering dan 2.93 ton/ha polong kering, sedangkan sistem tanam konvensional 1.67 ton/ha biji kering dan 2.55 ton/ha polong kering. Perlakuan jenis pupuk berbeda nyata terhadap produktivitas polong kering per ha dan tidak berbeda nyata terhadap produktivitas biji kering/ha (Tabel 7). 
Tabel 7. Produktivitas tanaman kacang tanah pada perlakuan tunggal sistem tanam dan jenis pupuk

\begin{tabular}{lcccc}
\hline Perlakuan & $\begin{array}{c}\text { Produktivitas polong } \\
\text { kering }\end{array}$ & $\begin{array}{c}\text { Produktivitas biji } \\
\text { kering }\end{array}$ & $\begin{array}{c}\text { Produktivitas polong } \\
\text { kering } \\
\ldots \ldots \ldots \ldots\left(\mathrm{g} \mathrm{m}^{-2}\right) \ldots \ldots \ldots . .\end{array}$ & $\begin{array}{c}\text { Produktivitas biji } \\
\text { kering }\end{array}$ \\
\hline Sistem Tanam & & & & \\
Alur & $433.36 \mathrm{a}$ & $281.88 \mathrm{a}$ & $2.93 \mathrm{a}$ & $1.90 \mathrm{a}$ \\
Konvensional & $372.53 \mathrm{~b}$ & $242.47 \mathrm{~b}$ & $2.55 \mathrm{~b}$ & $1.67 \mathrm{~b}$ \\
Jenis pupuk & & & & \\
Pukan & $358.1 \mathrm{c}$ & $247.40 \mathrm{a}$ & $2.52 \mathrm{~b}$ & $1.74 \mathrm{a}$ \\
Pukan+Dolomit & $401.59 \mathrm{~b}$ & $260.17 \mathrm{a}$ & $2.67 \mathrm{~b}$ & $1.73 \mathrm{a}$ \\
Pukan+Dolomit+N & $449.3 \mathrm{a}$ & $278.95 \mathrm{a}$ & $3.03 \mathrm{a}$ & $1.88 \mathrm{a}$ \\
PK & &
\end{tabular}
$\begin{array}{ll}\text { Keterangan : } & \begin{array}{l}\text { angka- angka pada kolom faktor tunggal yang sama pada tiap peubah diikuti huruf yang sama menunjukkan tidak } \\ \text { berbeda nyata pada uji Duncan taraf } 5 \%\end{array}\end{array}$

Interaksi antara sistem tanam dengan jenis pupuk berpengaruh nyata terhadap produktivitas polong kering. Sistem tanam alur maupun konvensional dengan pemberian jenis pupuk kandang + Dolomit + NPK memberikan produktivitas polong kering lebih baik dari kombinasi jenis pupuk lainnya (Tabel 7). Lukitas (2006) menyatakan bahwa pemberian pupuk kandang, suplai unsur hara pada tanaman kacang tanah tidak terhenti setelah unsur hara yang berasal dari pupuk anorganik dikonsumsi oleh tanaman terlebih dahulu. Terjaminnya ketersediaan unsur hara menyebabkan pertumbuhan tanaman pada fase generatif lebih baik.

Tabel 8. Produktivitas polong kering kacang tanah hasil interaksi perlakuan sistem tanam dan jenis pupuk

\begin{tabular}{|c|c|c|c|}
\hline \multirow{2}{*}{ Sistem tanam } & \multicolumn{3}{|c|}{ Jenis pupuk } \\
\hline & Pupuk kandang & Pupuk kandang + Dolomit & Pupuk kandang + Dolomit + NPK \\
\hline Alur & $2.8 \mathrm{ab}$ & $2.86 \mathrm{ab}$ & 3.13a \\
\hline Konvensional & $2.24 \mathrm{c}$ & $2.49 b c$ & $2.92 a$ \\
\hline
\end{tabular}

\section{Analisis usaha tani}

Analisis usaha tani budidaya kacang tanah pada perlakuan sistem tanam alur dengan pemberian jenis pupuk kandang + Dolomit + NPK menghasilkan keuntungan lebih besar dibandingkan dengan sistem tanam konvensional. Pada sistem tanam konvensional jumlah pekerja yang dibutuhkan dalam luasan 1 ha adalah 147 HOK, sedangkan pada sistem tanam alur adalah 144 HOK. Selisih HOK tersebut terdapat pada kebutuhan tenaga kerja saat penyiapan lahan dan pemupukan. Tingkat kerumitan budidaya kacang tanah dengan sistem tanam alur dianggap petani lebih rumit dibandingkan sistem tanam konvensional, hal ini karena petani terbiasa menggunakan sistem tanam konvensional. Pendapatan petani adalah hasil pengurangan antara penerimaan kotor dan biaya usahatani (Muklis et al. 2012). Pendapatan bersih yang diperoleh dari budidaya sistem tanam alur Rp 20025 000,00 sedangkan sistem tanam konvensional Rp 15620 000,00. Kacang tanah dengan sistem tanam alur maupun konvensional layak diusahakan. Hal ini dilihat nilai $\mathrm{R} / \mathrm{C}$ rasio yang diperoleh kedua sistem tanam tersebut lebih dari satu $(\mathrm{R} / \mathrm{C}>1)$, dimana sistem tanam alur 2.32 dan konvensional 2.02 artinya setiap penjualan harga Rp 1,00 mendapat keuntungan sebesar $\mathrm{Rp}$ 2.32,00 untuk sistem tanam alur dan Rp 2.02,00 untuk sistem tanam konvensional (Tabel 9 dan 10). 
Tabel 9. Analisis usaha tani kacang tanah sistem tanam konvensional

\begin{tabular}{|c|c|c|c|c|}
\hline No & Uraian & Volume (orang/hari) & Satuan biaya (Rp) & Jumlah biaya (Rp) \\
\hline \multirow[t]{11}{*}{ A } & Tenaga kerja & $147 \mathrm{HOK}$ & 50000 & 7350000 \\
\hline & - Penyiapan lahan & $15 \mathrm{HOK}$ & 50000 & 750000 \\
\hline & - Penanaman & 20 HOK & 50000 & 1000000 \\
\hline & - Pemupukan & $10 \mathrm{HOK}$ & 50000 & 500000 \\
\hline & - Penyiangan dan pembumbunan & $30 \mathrm{HOK}$ & 50000 & 1500000 \\
\hline & - Penyemprotan & $4 \mathrm{HOK}$ & 50000 & 200000 \\
\hline & - Pengairan & $3 \mathrm{HOK}$ & 50000 & 150000 \\
\hline & - Panen & 30 HOK & 50000 & 1500000 \\
\hline & - Pengangkutan & $15 \mathrm{HOK}$ & 50000 & 750000 \\
\hline & - Pengeringan & $10 \mathrm{HOK}$ & 50000 & 500000 \\
\hline & - Perontokan & $10 \mathrm{HOK}$ & 50000 & 500000 \\
\hline \multirow[t]{7}{*}{$\mathrm{B}$} & Sarana produksi & & & 4925000 \\
\hline & - Benih *) & $120 \mathrm{~kg}$ & 25000 & 3000000 \\
\hline & - Pupuk NPK Phonska & $200 \mathrm{~kg}$ & 3500 & 700000 \\
\hline & - Dolomit & 600 kg & 1000 & 600000 \\
\hline & - Pupuk Kandang Ayam & $1000 \mathrm{~kg}$ & 300 & 300000 \\
\hline & - Bio Hayati & 5 bks & 45000 & 225000 \\
\hline & - Pestisida & $1 \mathrm{ltr}$ & 100000 & 100000 \\
\hline \multirow[t]{2}{*}{$\mathrm{C}$} & Pengeluaran lain-lain & & & 3000000 \\
\hline & - Sewa lahan/ha/musim & Per m2 & 3000000 & 3000000 \\
\hline \multicolumn{2}{|c|}{ Total biaya produksi } & & & 15275000 \\
\hline & - Harga jual produksi *) & $1670 \mathrm{~kg}$ & $\left.18500^{* *}\right)$ & 30895000 \\
\hline & - Pendapatan bersih & & & 15620000 \\
\hline & - $\mathrm{R} / \mathrm{C}$ & & & 2.02 \\
\hline
\end{tabular}

Tabel 10. Analisis usaha tani kacang tanah sistem tanah alur

\begin{tabular}{|c|c|c|c|c|}
\hline No & Uraian & Volume (orang/hari) & Satuan biaya (Rp) & Jumlah biaya (Rp) \\
\hline \multirow[t]{11}{*}{ A } & Tenaga kerja & $144 \mathrm{HOK}$ & 50000 & 7200000 \\
\hline & - Penyiapan lahan & $14 \mathrm{HOK}$ & 50000 & 700000 \\
\hline & - Penanaman & $20 \mathrm{HOK}$ & 50000 & 1000000 \\
\hline & - Pemupukan & $9 \mathrm{HOK}$ & 50000 & 450000 \\
\hline & - Penyiangan dan Pembumbunan & $29 \mathrm{HOK}$ & 50000 & 1450000 \\
\hline & - Penyemprotan & $4 \mathrm{HOK}$ & 50000 & 200000 \\
\hline & - Pengairan & $3 \mathrm{HOK}$ & 50000 & 150000 \\
\hline & - Panen & $30 \mathrm{HOK}$ & 50000 & 1500000 \\
\hline & - Pengangkutan & $15 \mathrm{HOK}$ & 50000 & 750000 \\
\hline & - Pengeringan & $10 \mathrm{HOK}$ & 50000 & 500000 \\
\hline & - Perontokan & $10 \mathrm{HOK}$ & 50000 & 500000 \\
\hline \multirow[t]{7}{*}{ B } & Sarana produksi & & & 4925000 \\
\hline & - $\quad$ Benih *) & $120 \mathrm{~kg}$ & 25000 & 3000000 \\
\hline & - Pupuk NPK Phonska & $200 \mathrm{~kg}$ & 3500 & 700000 \\
\hline & - Dolomit & $600 \mathrm{~kg}$ & 1000 & 600000 \\
\hline & - Pupuk Kandang Ayam & $1000 \mathrm{~kg}$ & 300 & 300000 \\
\hline & - Bio hayati & 5 bks & 45000 & 225000 \\
\hline & - Pestisida & $1 \operatorname{ltr}$ & 100000 & 100000 \\
\hline \multirow[t]{2}{*}{$\mathrm{C}$} & Pengeluaran lain-lain & & & 3000000 \\
\hline & - Sewa lahan/ha/musim & Per m2 & 3000000 & 3000000 \\
\hline \multicolumn{2}{|c|}{ Total biaya produksi } & & & 15125000 \\
\hline & - Harga jual produksi *) & $1900 \mathrm{~kg}$ & $\left.18500^{* *}\right)$ & 35150000 \\
\hline & - Pendapatan bersih & & & 20025000 \\
\hline & - $\mathrm{R} / \mathrm{C}$ & & & 2.32 \\
\hline
\end{tabular}

Keterangan : Deptan (2013) *) Bentuk biji kering; ${ }^{* *}$ ) Info harga kementrian perdagangan RI (2013) 


\section{KESIMPULAN}

Budidaya kacang tanah sistem tanam alur dapat meningkatkan efisiensi tanaman dalam memanfaatkan unsur hara yang telah diberikan baik pupuk organik maupun anorganik, sehingga pertumbuhan dan hasil tanaman kacang tanah menjadi lebih baik. Pemberian jenis pupuk kandang + Dolomit + NPK memberikan pengaruh terhadap pertumbuhan dan daya hasil rata-rata tanaman yang lebih baik dibandingkan jenis pupuk lainnya. Pertumbuhan dan hasil kacang tanah budidaya sistem tanam alur menghasilkan nilai interaksi dengan perlakuan ketiga jenis pupuk lebih baik dibandingkan sistem tanam konvensional, namun pada sistem tanam konvensional memberikan pertumbuhan kacang tanah yang sama baiknya pada pemberian jenis pupuk kandang + Dolomit + NPK.

\section{DAFTAR PUSTAKA}

[Balitkabi] Balai Penelitian Tanaman Kacangkacangan dan Umbi-umbian. 2008. Teknologi Produksi Kacang Tanah. Balai Penelitian Tanaman Kacangkacangan dan Umbi-umbian. Malang (ID): Badan Penelitian dan Pengembangan Pertanian.

[BPS] Badan Pusat Statistik. 2013. Produksi Tanaman Pangan. [Internet]. [diunduh 26 Januari 2013]. Tersedia pada: http://www.bps.go.id/tnmn_pgn.php

[Deptan] Departemen Pertanian. 2013. Analisis usaha tani [Internet]. [diunduh 8 September 2013]. Tersedia pada: http://tanamanpangan.deptan.go.id

Direktorat Jendral Tanaman Pangan. 2012. Pengelolaan Produksi Tanaman Aneka Kacang dan Umbi Tahun 2012. Jakarta (ID): Direktorat Jendral Tanaman Pangan.

Harsono, A. 2007. Kekeringan pada kacang tanah di lahan kering dan penanggulangannnya. $\mathrm{Di}$ dalam: Harnowo D, Rahmianna AA, Suharsono, Adie MM, Rozi F, Subandi, Makarim AK, penyunting. Peningkatan Produksi Kacang-kacangan dan Umbi-umbian Mendukung Kemandirian Pangan; Waktu pertemuan (8 September 2006); Malang. Indonesia. Bogor (ID): Pusat
Penelitian dan Pengembangan Tanaman Pangan. 347-357.

Jumakir, Waluyo, Suparwoto. 2000. Kajian berbagai kombinasi pengapuran dan pemupukan terhadap pertumbuhan dan produksi kacang tanah (Arachis hypogaea L.) dilahan pasang surut. $J$ Agron. 8(1):11-15.

Kadekoh, I. 2007. Komponen hasil dan hasil kacang tanah berbeda jarak tanam dalam sistem tumpangsari dengan jagung yang didefoliasi pada musim kemarau dan musim hujan. J Agroland. 14(1):11-17.

Kari, Z, Yuliar Z, Suhartono. 2000. Pengaruh pupuk kalium (K) dan pupuk kandang terhadap pertumbuhan dan hasil kacang tanah. J Stigma. 8(2): 123-126.

Kasno A. 2005. Profil dan perkembangan teknik produksi kacang tanah di Indonesia. Seminar Rutin Puslitbang Tanaman Pangan. Bogor (ID): Pusat Penelitian dan Pengembangan Tanaman Pangan.

[Kemendag] Kementrian Perdagangan. 2013. Daftar Harga Sembako [Internet]. [diunduh 28 Juni 2013]. Tersedia pada: http://ews.kemendag.go.id

Lukitas, W. 2006. Uji daya hasil lima kultivar kacang tanah [skripsi]. Bogor (ID): Institut Pertanian Bogor. Marzuki R. 2009. Bertanam Kacang Tanah. Jakarta (ID): Panebar Swadaya.

Muklis, I, Wicaksono IA, Hasanah U. 2012. Analisis usahatani kacang tanah (Arachis hypogaea, L.) di Desa Pasar Anom Kecamatan Grabag Kabupaten Purworejo. Surya Agritama. 1:46-56.

Pitojo, S. 2005. Benih Kacang Tanah. Yogyakarta (ID): Kanisius.

Purnamawati, H, Poerwanto R, Lubis I, Yudiwanti, Rais SA, Manshuri AG. 2010. Akumulasi dan distribusi bahan kering pada beberapa varietas kacang tanah. J Agron Indonesia. 38(2):100106.

Purnamawati, H. 2011. Analisis potensi hasil kacang tanah dalam kaitan dengan kapasitas dan aktivitas sources dan sink 
[disertasi]. Bogor (ID): Institut Pertanian Bogor.

Ratnapuri, I. 2008. Karakteristik pertumbuhan dan produksi lima varietas kacang tanah (Arachis hypogaea L.) [skripsi]. Bogor (ID): Institut Pertanian Bogor.

Risdiyanto, I, Setiawan R. 2007. Metode neraca energi untuk perhitungan indeks luas daun mrnggunakan data citra satelit multi spektal. $J$ Agromet Indonesia. 21(2):27-28.

Sumarno, Hartati S, Widjianto H. 2001. Kajian macam pupuk organik dan dosis pupuk $\mathrm{P}$ terhadap hasil kacang tanah (Arachis hypogaea L.) di tanah latosol. Sains Tanah. 1(1):1-6.
Sutrisno. 2004. Studi Dosis Pupuk dan Jarak Tanam Kacang Tanah (Arachis hypogaea, L.). Pati (ID): Kantor Litbang Kabupaten Pati.

Yudiwanti, Sudarsono, Purnamawati H, Yusnita, Hapsoro D, Hemon AF, Soenarsih S. 2008. Perkembangan Pemuliaan Kacang Tanah di Institut Pertanian Bogor. Di dalam: Harsono A, Taufiq A, Rahmianna AA, Suharsono, Adie MM, Rozi F, Wijanarko A, Widjono A, Soehendi R, Penyunting. Inovasi Teknologi Kacangkacangan dan Umbi-umbian Mendukung Kemandirian Pangan dan Kecukupan Energi; (9 November 2007); Malang. Indonesia. Bogor (ID): Pusat Penelitian dan Pengembangan Tanaman Pangan. 152-160. 